Meta

Journal des traducteurs

Translators' Journal

\title{
Whose Face? Us and them in English - Polish Consecutive Interpreting
}

\section{Krystyna Warchał, Andrzej Łyda et Alina Jackiewicz}

Volume 56, numéro 4, décembre 2011

URI : https://id.erudit.org/iderudit/1011252ar

DOI : https://doi.org/10.7202/1011252ar

Aller au sommaire du numéro

\section{Éditeur(s)}

Les Presses de l’Université de Montréal

ISSN

0026-0452 (imprimé)

1492-1421 (numérique)

Découvrir la revue

Citer cet article

Warchał, K., łyda, A. \& Jackiewicz, A. (2011). Whose Face? Us and them in English - Polish Consecutive Interpreting. Meta, 56(4), 775-795.

https://doi.org/10.7202/1011252ar

\section{Résumé de l'article}

Les auteurs s'intéressent à une situation dans laquelle les préoccupations relatives à la face (dans le sens de dignité) du récepteur et/ou l'identité de l'interprète et son appartenance à un groupe peuvent devenir des facteurs influençant le processus d'interprétation. L’objectif du présent article est d'examiner la performance des étudiants interprètes avancés dans un contexte d'interprétation consécutive comportant une critique ouverte ou une louange directe de l'auditoire de la langue cible. Plus particulièrement, les auteurs traitent du type et de l'étendue de la figuration effectuée dans les tâches comportant des actes à la suite desquels le récepteur pourrait perdre la face. Ils s'intéressent également à la corrélation éventuelle entre la performance de l'interprète au cours de ces tâches, ses choix et sa relation avec le groupe des récepteurs finaux.
Ce document est protégé par la loi sur le droit d'auteur. L'utilisation des services d’Érudit (y compris la reproduction) est assujettie à sa politique d'utilisation que vous pouvez consulter en ligne.

https://apropos.erudit.org/fr/usagers/politique-dutilisation/ 


\title{
Whose Face? Us and them in English - Polish Consecutive Interpreting
}

\author{
KRYSTYNA WA RCHAE \\ University of Silesia, Sosnowiec, Poland \\ ktotampuka@gmail.com
}

\section{ANDRZEJ LYDA}

University of Silesia, Sosnowiec, Poland

andrzejlyda@gmail.com

ALINA JACKIEW ICZ

University of Silesia, Sosnowiec, Poland

alina.jackiewicz@neostrada.pl

\begin{abstract}
RÉSUMÉ
Les auteurs s'intéressent à une situation dans laquelle les préoccupations relatives à la face (dans le sens de dignité) du récepteur et/ou l'identité de l'interprète et son appartenance à un groupe peuvent devenir des facteurs influençant le processus d'interprétation. L'objectif du présent article est d'examiner la performance des étudiants interprètes avancés dans un contexte d'interprétation consécutive comportant une critique ouverte ou une louange directe de l'auditoire de la langue cible. Plus particulièrement, les auteurs traitent du type et de l'étendue de la figuration effectuée dans les tâches comportant des actes à la suite desquels le récepteur pourrait perdre la face. Ils s'intéressent également à la corrélation éventuelle entre la performance de l'interprète au cours de ces tâches, ses choix et sa relation avec le groupe des récepteurs finaux.
\end{abstract}

\section{ABSTRACT}

The authors are interested in a situation where concern for the face of the receiver and/ or the identity and group membership of the interpreter can become factors that influence the process of interpreting. The aim of this paper is to look into the performance of advanced trainee interpreters in consecutive interpreting tasks that involve open criticism or direct praise of the target audience. More specifically, the authors are concerned with the type and extent of face-work carried out in tasks involving face-threatening acts and with the possible correlation between the interpreter's performance in such tasks, the choices made by the interpreter and his or her relationship with the group of ultimate receivers.

\section{MOTS-CLÉS/KEYWORDS}

interprétation consécutive, face, déplacement déictique, empathie, manipulation consecutive interpreting, face, deictic shift, empathy, manipulation

\section{Introduction}

As the primary receiver and the secondary sender of a message, the interpreter is, as Hatim and Mason (1997: 2) note, "a special category of communicator [...] whose act of communication is conditioned by another, previous act and whose reception of that previous act is intensive." As any other communicator, the interpreter is involved in a verbal exchange and interested in producing a contribution which is cohesive, 
coherent, well-judged with respect to the communicative intention, immediate context, and background knowledge and expectations of the other participants in the communicative event. S/he is present on the communicative scene with his or her own baggage of experiences, knowledge, and beliefs, living, as Bell (1991: 15-16) observes, "in the world of the senses through which perceptions are integrated as concepts, experiences can be 'recalled' and even 'relived' through the systems of memory." S/he displays his or her public self-image defined with regard to socially accepted values (Goffman 1967: 5), his or her face of a qualified professional, whose product undergoes a continuous assessment by its end-users (see, e.g., Cooper, Davies et al. 1982; Kurz 1997; Jiménez Ivars and Pinazo Calatayud 2001), competent language user and self-conscious individual endowed with social skills, sensitivity and tact. Unlike other communicators, though, his or her communicative behaviour is constrained by the previous act of communication by a different speaker, whose communicative goals, which in most cases do not become clear until the text unfolds, must be reconstructed, whose experiences, knowledge and beliefs are not the interpreter's, and whose contribution is to be re-encoded in another language in such a way so as not to belie them.

The constraints imposed on the interpreter as a communicator by his or her role as an intermediary in the communicative event may result in risks to his or her face of an adult, educated and competent member of the society, which is subordinated to competence, wants, and needs of the primary sender. At the same time, as a mediator between the primary sender and the ultimate receiver, the interpreter is responsible for the successful interaction - for the transfer of the propositional content and for its reception in accordance with the primary sender's intention. Therefore, apart from attending to the content, the interpreter must pay close attention to such elements of the context as assumed knowledge of the ultimate receivers and their face, whose maintenance minimises the risk of other interactants' face being threatened. As noted by Brown and Levinson (1987: 61), "normally everyone's face depends on everyone else's being maintained." Hence it is also the responsibility of the interpreter to realise potential threats to face and to prevent them if they can ruin the intended effect of the message, e.g., by causing offence or embarrassment. The highly culture-bound problem of face and face-work - actions undertaken by a communicator to achieve consistency with face (Goffman 1967: 12) - may be viewed as one of the reasons for the interpreter acting, and being expected to act, as a "cultural mediator" (Kurz 2001: 400).

In this analysis we see the tension between accurate translation, focused on completeness and accuracy of the content, which, as Kurz (2001) reports, are the criteria most frequently referred to as crucial in the assessment of the quality of interpreting, and translation for equivalent effect, with the interests and intentions of the primary sender being of prime importance, aptly illustrated by Pöchhacker (2001: 413-414) in his discussion of quality standards for the product and service of interpreting, in terms of tension between face-wants which are difficult to reconcile. On the one hand, the need to display professional skills, such as language competence, high precision, effective time management and orientation in the subject matter, will prompt the interpreter to aim at maximum accuracy and completeness of the output in order to prevent potential loss to his or her professional face. On the other hand, the concern for the face of the speaker and the audience will call for 
closer attention being paid to the effect the message has and to the ultimate success of communication, sometimes leading to omissions or additions to the target text and to weakening or strengthening of its illocutionary force with regard to the source text, as shown, e.g., by Monacelli (2009) in a recent study on interpreters' professional survival strategies. Finally, there is the face of the interpreter as a member of the society, with his or her beliefs, values, in-group loyalties and attitudes, which may, in certain circumstances, reflect the interpreter's stance towards the communicating parties (see, e.g., Angermeyer 2005a) or interfere with the practice of interpreting, as pointed out, e.g., by Wong and Shen (1999).

The present study rests on and builds from Brown and Levinson's theory of politeness with its underlying concepts of 'face,' 'face-saving' and 'face-threatening.' We use the term politeness in the sense proposed by the two authors, i.e., as has often been pointed out in literature, in the sense of 'second-order politeness,' a scientific conceptualization of 'first-order politeness' understood as politeness-as-practice in everyday interaction (see, e.g., Ehlich 1992). In Brown and Levinson (1987) politeness is conceptualized as the realisation of face threat mitigation, where 'face,' a concept originating in the work of Goffman (1967), is defined as:

the public self-image that everyone lays claim to, consisting of two related aspects:

a) negative face: the basic claim to freedom of action and freedom from imposition;

b) positive face: positive self-image and the desire that this self-image be appreciated and approved of. (Brown and Levinson 1987: 61)

According to the theory, in an interactional dyad most speech acts are inherently threats to the face, either to the hearer's or the speaker's, and as such require a substantial face-work consisting in redressive maneuvers on the part of the speaker. These include, among others, strategies of positive politeness by attending to the hearer's positive face-wants, negative politeness addressing the social distance between the interlocutors and off-record strategies based on indirectness or ambiguity.

Brown and Levinson's theory has rarely been regarded as uncontroversial (see, e.g., Eelen 2001). Among the objections raised the gravest one concerned the very hope expressed by these authors that their model is universally valid and as such can be a means "to characterize the cross-cultural differences in ethos, the general tone of social interaction in different societies" (Brown and Levinson 1987: 253). The claim of universality has attracted wide criticism with a battery of arguments related to the Anglo-centrism of this model of politeness, the allegedly "paranoid" approach to communication as "fundamentally dangerous and antagonistic behaviour" (Kasper 1990: 194), and the neglect of the socio-cultural context in which the politeness mechanisms operate (House 2005), to name a few. In spite of the criticism resulting in the emergence of alternative theories, such as Fraser's Conversational Contract (Fraser 1990), Spencer-Oatey's theory of rapport-management and group identity (Spencer-Oatey 2000) and Watts's relational work approach (Watts 2003; Locher and Watts 2005), the last two decades have seen a phenomenal growth in interest in politeness. This interest on the part of theoreticians and language researchers has evolved from early preoccupation with cross-linguistic studies also to the area of translation and interpreting, with at least two distinct strands of research.

The first one involves studies focusing on screen translation. Of considerable importance for translation theory and practice is the work of Hatim and Mason (1997), who analyse the translation of film subtitles and of sacred and sensitive texts 
to point out that to achieve an equivalent effect translators often resort to adjusting for different politeness codes in the target culture. An important contribution in the area of film translation comes also from Zitawi (2008), who examines Brown and Levinson's politeness theory in the context of Disney comics translation in the Arab culture. While finding the model applicable to an analysis of the genre, the author argues for a number of modifications necessary for an analysis of complex genres translated between two different cultures.

The other strand of research into the problem of politeness includes studies pertaining to courtroom interpreting. In many works (e.g., Mason and Stewart 2001; Jacobsen 2008) Brown and Levinson's theory forms the basis for the discussion of means of recreating (or failure to recreate) face-threatening or face-saving illocutionary force and the management of face-work. Others (e.g., Angermeyer 2005b; Leung and Gibbons 2008) refer indirectly to the theory of face by discussing the issue of participant roles in interpreting court cases.

In this small-scale research we also ask questions concerning the role of the interpreter or rather his/her identity. We are interested in a situation where concern for the face of the receiver and/or the identity and group membership of the interpreter can become factors that influence the practice of interpreting. In particular, we will look into the interpreter's treatment of direct criticism and praise in public addresses if these are levelled at the audience. We will also examine a case where one can suspect in-group bias in the interpreter's treatment of such explicit evaluation.

\section{The Study}

\subsection{Objectives}

Consecutive interpreters have access to larger portions of text before they start production. Information must be understood, analysed and re-expressed sometimes several minutes after the primary sender started speaking. This presents an additional load on the memory on the one hand, and offers insight into the structure of the text on the other - it allows the interpreter to (partially) reconstruct the communicative goal of the primary sender before interpretation and to determine in what moves this goal is to be achieved. Hence, as Hatim and Mason (1997: 49) show, text structure, the compositional plan of a text, receives prominence in the consecutive mode, while decisions concerning the texture are made with a view to adequately representing this structure, be it counter-argumentative, expositional or other. Linguistic choices made by the primary speaker on the level of texture are motivated - by the communicative goal, immediate context and by the text structure, which is selected to best advance the communicative purpose. If the linguistic choices made by the interpreter, who is aware of the structure of the text and consciously attends to it, are consistently different from the linguistic patterns observed in the source text, questions arise as to the motivation of such choices. While these differences can often be explained in terms of distinct language systems, some such occurrences seem to be related to other factors. We are concerned here with face or, more exactly, faces as factors that can motivate such differences.

The aim of this paper is to look into the performance of advanced trainee interpreters in consecutive interpreting tasks that involve open criticism or direct praise of the 
target audience. More specifically, we are concerned with the type and extent of face-work carried out in simulated data monologic tasks involving face-threatening acts and with the possible correlation between the interpreter's performance in such tasks and his or her relationship with the group of ultimate receivers. An argument in favour of using monologic texts, in which the possible face-threatening acts may be of less direct consequences than in dialogue interpreting, was that immediately prior to the experiment the trainee interpreters had been practising consecutive interpreting of formal speeches. The decision to use texts formally corresponding to the previous ones was taken to ensure that the text should be perceived by the trainees as 'generically unmarked' and naturally congruent with the trainee's syllabus and their recent interpreting tasks - in an attempt to reduce the risk of a biased approach to the texts under analysis.

In what follows we will seek answers to the following questions: i) Are there any systematic differences between the interpreter's treatment of direct criticism and praise whose objects are the ultimate receivers of the message? ii) Does the fact that the interpreter identifies with the group of ultimate receivers influence the treatment of direct criticism and praise receive in interpreting tasks? iii) Is there any regularity in the choices made by the interpreter that may reflect in-group bias in the treatment of explicitly evaluative discourse?

\subsection{Subjects}

Data for analysis were obtained from four groups of trainee interpreters studying translation and interpreting in the English Department of the University of Silesia, two groups comprising advanced interpreters with 5-semester experience in consecutive interpreting prior to the study $\left(5^{\text {th }}\right.$ year students) and two groups of trainees with 3-semester experience ( $4^{\text {th }}$ year students). All the subjects were Polish students of English (language B), taking either German or Arabic (language C) as their minor. There were on average 15 students in each group.

\subsection{Source Texts}

For the purpose of this study five texts were prepared in English, all of them monologic, formal (Newmark 1988: 14) addresses, presented orally by male speakers to different groups of receivers (see Appendix). Their length varied from 565 to 688 words. The STs were delivered at an average pace of about 108 words/min and recorded with pauses, three shorter texts divided into two units, the others into three. ${ }^{1}$

The speeches were presented to the subjects as if they had actually been delivered on a specific occasion and at that time recorded. In the instruction to the interpreting tasks students were informed about the identity of the speaker, the audience he addressed and the original receiver of the TT. STs 1 and 2 were addressed to students of English at the University of Silesia and interpreted for the benefit of those whose language proficiency was below average and the non-English speaking staff. In the case of STs 3 and 4, the addressees were members of national Olympic Teams (Australian and British respectively), their interpretation produced for representatives of the Polish Olympic Team invited to participate in the event. ST5 was addressed to participants of the Annual State Congress of Real Estate Enterprise and 
interpreted for members of the Polish community abroad who took part in the proceedings. The trainee interpreters participating in the tasks were told they were working on real speeches, that is, on texts that had actually been produced in concrete situations, with the result that some of them, understandably concerned about texts which addressed their community, explicitly asked for details of STs 1 and 2 after completion of the tasks.

The STs, prepared especially for this study, contain only active constructions and no impersonal forms. The speaker speaks in the first person singular and is the source of evaluation, information or judgment. Even if he represents an institution or organisation, it is the primary speaker who bears the responsibility for the statements he makes and is empowered to make such statements (e.g., by acting as Head of a department and hence entitled to impose penalties). The second person pronoun always refers to the audience, whose members are directly addressed by the speaker. STs 1-4 are structurally similar, with STs 1 and 3 expressing negative evaluation of the audience and STs 2 and 4 expressing positive judgment. In each of the four STs the pronoun $I$ is used 16 times and the pronoun you 21 times in the subject position. ST5 is warm in tone (Newmark 1988: 14) but, unlike the other STs, informative rather than evaluative, although the information transferred is positively evaluated by the speaker.

In ST1 the speaker, Co-ordinator for Student Mobility at the European Commission Department for Education, Training, Culture and Youth, addresses students of English at the University of Silesia to reproach them for their poor performance and attitude and to inform them about the possible dire consequences of their conduct. In ST2 Co-ordinator for Human Resource Development at the European Commission Department for Education, Training, Culture and Youth thanks students of English at the University of Silesia for their excellent work for the benefit of the international student community and compliments them on their creativity and competence. In the case of ST1 and ST2, evaluative acts affect both audiences, that of the English speech and that of its Polish interpretation. In ST3 the President of the Australian Wines Inc., official sponsor of the Australian Olympic Team, addresses members of the Australian Olympic Team 2008 to criticise them for their poor performance and attitude during the last Olympic Games. In ST4 the President of the British Olympic Association thanks members of the British Olympic Team 2008 for their outstanding performance in the same event. With regard to ST3 and ST4, evaluative acts affect the receivers of the English speech but not those of the TT. Finally, in ST5 the President of the Texas Association of Realtors addresses the participants of the Annual State Congress of Real Estate Enterprise to present the annual report of the Association's performance. The analysis is based on STs 1-4, with ST5 acting as a control text sample

For STs 1-4 focal points were identified, which later served as a point of reference in the analysis of the outputs. All focal points involved tensed verb forms with firstperson singular and second-person subjects. For each of the STs 37 focal points were identified, 16 with $I$ in the subject position and 21 with you as the subject.

\subsection{Procedure}

Outputs were recorded during six sessions between March $19^{\text {th }}$ and April $2^{\text {nd }} 2009$, on average with 24 students per session. Students interpreted in blind booths, having been advised on the identity of the speaker and the audience addressed by the speaker 
prior to the task. They were instructed to interpret with a specific group of receivers in mind. In this period of time each student was asked to interpret at least two texts.

Altogether 129 outputs were collected (damaged or illegible recordings eliminated on the spot), including 33 samples of ST1, 33 samples of ST2, and 21 samples of each of the remaining STs. Among those 129 outputs only 29 were by male interpreters.

The analysis was based on 50 randomly chosen outputs but with controlled parameters of gender and experience of the interpreter. The aim was to include equal numbers of male and female subjects for each of the STs and to monitor the experience of male and female trainees working on each interpreted text. Thus 10 samples for each ST were included, where 5 came from male and 5 from female students. Outputs produced by $5^{\text {th }}$ year students accounted for $50 \%$ of the analysed material, with 5 samples for each ST.

Next, transcripts of the 50 outputs were prepared and analysed in terms of the treatment of propositions marked as focal in the STs. Data collected in this way were then ordered to categories which were data-based rather than pre-defined and which involved: i) passive voice and impersonal constructions; ii) nominalisations; iii) other forms of modulation; and iv) manipulation of the deictic perspective. It has been demonstrated in numerous studies that none of these four labels can be readily dismissed as unrelated to the problem of face and face-work. On the contrary, the relevant literature abounds in studies demonstrating their exploitation in the construction of one of many possible representations of a particular event and, more generally, in encoding in language our experience and world-view. Simpson (1993) demonstrates the ideological consequences of the use of the passive voice in the media. Similarly, Fowler's (1991) analysis of nominalisation clearly shows the ideological opportunities offered by the unexpressed information hidden in a derived nominal clause. Also Łyda, Warchał et al. (2011) argue that nominalisation as a form of the representation of the semantic relation agent - activity suspends the relation or at least blurs it by separating the agent from the activity, thus distancing the action from its performer, which in certain cases may be interpreted as a FTA avoidance strategy. A similar 'distancing' effect can be achieved through a number of procedures often jointly presented under the heading 'modulation,' i.e., "a variation through change of viewpoint, of perspective [...]” (Newmark 1988: 88), and, finally, through the manipulation of the deictic centre (see below).

The large amount of data obtained in the experiment makes it virtually impossible to discuss all these categories within the confines of an article. For this reason our main focus will be on the last-mentioned category, as the least-studied one and observed most frequently in our data.

\section{Results}

The term deixis covers such aspects of a communicative event as the identity of the interlocutors, the time at which communication takes place, the location of the interlocutors at the time of communication, references to other portions of the ongoing discourse, and expressions which reflect the relative social status between the participants as perceived by the speaker (Fillmore 1971: 219-220). Deixis anchors language in the real world by establishing the deictic centre, the point of reference from which a state or event is looked upon along these various dimensions of person, time, space, cohesion and status, and by supplying a point of view from which this state or 
event is evaluated (Verschueren 1999: 18). Any instance of manipulation of the deictic centre or a shift in the perspective on the totality of the speech event involves a change in the distance between the participants, which in interpreting tasks is often a signal of complex facework on the part of the interpreter - a case illustrated by Monacelli (2009) in her discussion of interactional politeness mechanisms. This observation prompted interest in what happens with person deixis in the interpretations of the STs under discussion.

Generally speaking, we have observed three types of deictic shift: first-person singular subject to first-person plural subject; second-person subject to first-person plural subject; and second-person subject to third-person plural subject (Table 1).

TABLE 1

Deictic shifts in STs by type of transformation; STs 1-4 with 16 occurences of $I$ and 21 occurences of you each

\begin{tabular}{|l|c|c|c|c|c|c|}
\hline $\begin{array}{l}\text { source text / } \\
\text { deictic shift }\end{array}$ & ST1 & ST2 & ST3 & ST4 & $\begin{array}{c}\text { total STs } \\
\mathbf{1 - 4}\end{array}$ & $\begin{array}{c}\text { ST5 (control text } \\
\text { sample) }\end{array}$ \\
\hline I-WE & 5 (excl.) & 1 (incl.) & 0 & $\begin{array}{c}1 \text { (incl.) } \\
3 \text { (excl.) }\end{array}$ & 10 & 3 (incl.) \\
\hline YOU-WE & 2 (incl.) & $\begin{array}{c}1 \text { (incl.) } \\
1 \text { (?) }\end{array}$ & 2 (incl.) & 7 (incl.) & 13 & 3 (incl.) \\
\hline YOU-THEY & 40 & 31 & 0 & 1 & 72 & 11 \\
\hline total & 47 & 34 & 2 & 12 & 95 & 18 \\
\hline
\end{tabular}

\subsection{I to WE Shift}

Instances of first-person singular to first-person plural shift in the subject position were recorded in the outputs produced for STs 1, 2 and 4. Out of the 10 shifts observed, 5 occurred in four interpretations of ST1, 1 in ST2, and 4 in two interpretations of ST4 (2 in each TT). As regards ST1, all the five occurrences, coming from four different outputs, involved exclusive WE, which did not embrace the audience but referred to the speaker as part of a larger body, in whose power it is to supervise, to evaluate and to penalise (Example 1). It is worth noting that these shifts were recorded in just three focal units where the role of the speaker as supervisor and assessor was most transparent (Examples 1-3).

(1) $[1-4 \mathrm{O}-8-\mathrm{M}]$ natomiast ostatnio zauważamy, że wy, studenci, nie przejawiacie zbytniego zainteresowania

however recently we have noted that you students do not show special interest [it is with sad disappointment that I noticed that you do not show more interest in international exchange projects] ${ }^{2}$

(2) [1-5O-5-F] jeśli wciąż... będą się powtarzały podobne sytuacje, będę musiał nałożyć [selfcor.] będziemy musieli nałożyć karę pieniężną na wasz instytut so if similar situations will recur, I will have to, we will have to impose a financial penalty on your institute [if you persist in this deplorable practice, as Co-ordinator for Student Mobility I will have to impose financial penalties on your Home Institution]

(3) [1-5O-10-F] postaramy się nałożyć na państwa, którzy nie biorą udziału w tych programach, nie biorą ich poważnie [selfcor.] na poważnie, nałożymy na nich grzywnę 
we will try to impose on you, who do not participate in these programmes, do not take them seriously, we will impose a fine on you [if you persist in this deplorable practice, as Co-ordinator for Student Mobility I will have to impose financial penalties on your Home Institution]

With regard to ST2, the deictic shift involved inclusive WE, embracing the speaker, the audience and other parties that might be involved (Example 4).

(4) [2-5O-4-F] ale musimy pamiętać o tym, że na atmosferę całego miejsca wpływają nie ściany, ale ludzie

but we have to remember about it that not walls but people influence the atmosphere of a whole place [I know it's not walls that have made this building into a dynamic centre of research and education]

First-person singular to first-person plural shifts were absent from the outputs produced for ST3, which, like ST1, involved direct criticism of the audience. In contrast to ST1, though, ST3 was addressed to a group of receivers with whom the interpreter could not identify. In this case, then, neither the interpreter nor the receivers of the interpretation were the objects of negative assessment.

In the outputs produced for ST4, one example of inclusive WE was recorded, which, unlike the examples quoted above, was not directly involved in passing judgment (Example 5).

(5) [4-5O-3-F] kiedy spotkaliśmy się w tym samym miejscu miesiąc temu when we met in the same place a month ago [when I stood here before you a month ago]

The other 3 instances recorded in two TTs for ST4 involve exclusive WE, which embraces the speaker and other British sport fans, and all introduce laudation (Example 6).

(6) [4-5O-1-F] jesteśmy dumni z waszych sukcesów i wiemy, że wasze podejście do tego, wasze oddanie

we are proud of your successes and we know that your attitude to it, your commitment [what I find exceptionally important, though, is the way in which you achieved this remarkable success]

As regards the control sample, all the 3 shifts involved inclusive WE, embracing the speaker and the audience. Unlike the exclusive WE in ST1 and in a way similar to the inclusive pronouns recorded in STs 2 and 4, here the shift appears to minimise the distance between the parties involved in the communicative event.

\subsection{YOU to WE Shift}

Second-person to first-person plural shifts were recorded in the outputs for all four STs under analysis. Altogether 13 such occurrences were noted, two in each of STs 1-3 and 7 in ST4. The two shifts in ST1 come from the same output, occur in adjacent focal points, and involve inclusive WE, which embraces the speaker, the audience, and the Faculty members (Example 7).

(7) [1-5O-4-F] na wydziale, na który zasłużyliśmy, my, pracownicy oraz studenci. czekaliśmy na niego bardzo długo

in the department which we, the staff and students, have deserved. We have waited for it a very long time [in this new and modern site, which this Faculty and above 
all you, future teachers, translators, interpreters and researchers have deserved for a long time and for which you had to wait for too long]

It is worth noting that this fragment comes from the first portion of the ST which the trainees were asked to interpret, and that at this stage the full impact of the text might not have been anticipated by the student. Interestingly, neither of these uses introduces negative evaluation and if they trigger emotions, these are positive rather than negative.

As in the case of ST1, the two shifts in ST2 come from the same interpreter and occur very close to each other. The second shift is combined with modulation, which results in the pronoun being moved from the subject to indirect object position (Example 8). While the second change represents inclusive WE transformation, the status of the first occurrence is ambiguous, referring either to all individuals and bodies responsible for the exchange and those directly benefiting from the exchange, the speaker and the audience included, or to those involved in the organisation of the exchange only and therefore excluding the addressees.

(8) [2-5T-1-M] między którymi to uniwersytetami utrzymujemy stałe wymiany studentów. to umożliwia nam nie tylko dzielenie się doświadczeniami, ale także wymianę informacji

universities with which we maintain student exchange on a regular basis. This enables us not only to share experiences but also to exchange information [you have managed to establish a regular exchange. This mobility became the basis for a translation student network that you have started and later developed into an invaluable source of information]

As regards ST3, the shifts were recorded in different outputs. Both instances are inclusive although their scope is different, with the first embracing the speaker and the audience (Example 9), and the other referring (metonymically) to 'Australia,' speaker and the addressees included (Example 10).

(9) [3-5O-1-F] zawiedliśmy atletów we disappointed athletes [you ... seriously disappointed your fellow athletes]

(10) [3-4O-1-F] w klasyfikacji generalnej znaleźliśmy się niżej niż takie kraje jak niemcy czy wielka brytania

in the general ranking we have found ourselves in a lower position than such countries as Germany or Great Britain [within just two weeks you demoted this country ... to the status of mediocrity]

In the interpretation presented in Example 9, the responsibility for the plight of the Australian team seems to be shared by the audience and the speaker, with the result that the critical force of the text is diluted. The use of the broadly inclusive pronoun WE, coupled with additional modulation in Example 10, alleviates criticism by stressing the undesirable result of an action rather than the action itself and may be taken as a symptom of solidarity with the audience, who are to blame for this state of affairs. It is worth noting that this 'empathic' shift is absent from interpretations of ST1, also critical.

As many as seven second-person to first-person plural shifts were found in six outputs for ST4, connected with only three focal points. All cases illustrate the use of broadly inclusive WE, embracing the speaker, the audience, British fans, and Great Britain (Examples 11-13). 
(11) [4-5O-2-F] uplasowaliśmy się za chinami, stanami zjednoczonymi i rosją, którzy są [selfcor.] którzy zawsze byli potęgą we hold the position behind China, United States and Russia, which are, which have always been power [you have promoted Britain to rank four, behind such Olympic giants as China, United States and Russian Federation]

(12) [4-4T-1-M] udało nam się zdobyć 13 srebrnych, 15 brązowych we have managed to win 13 silvers, 15 bronze medals [With 19 golds, 13 silvers and 15 brown medals you have shown the world]

(13) [4-4T-1-M] udało nam się utrzymać tradycję sportu, która jest bardzo żywa we have managed to maintain the sport tradition, which is very much alive [You have proved that the tradition of sports competition, fair play and cooperation is in Britain as much alive as ever]

In three interpretations of the same unit, there is a change in the focus from the action that has led to success to the desirable state resulting from the action (Example 11). This modulation, or shift of point of view, moves the agent responsible for the success into the background (Example 14).

(14) [4-4O-1-M] daje nam to czwarte miejsce za takimi gigantami jak chiny stany zjednoczone i rosja this gives us rank four behind such giants as China, United states and Russia [you have promoted Britain to rank four, behind such Olympic giants as China, United States and Russian Federation]

The other instances exemplify the effect of 'sharing the credit' for the success, as shown in Examples 12 and 13.

With regard to the 3 shifts noted in ST5, they all represent inclusive WE and refer to the knowledge which is assumed to be shared by the speaker and the audience.

\subsection{YOU to THEY Shift}

The second-person to third-person plural shift was observed in 72 cases, practically exclusively in STs 1 and 2, with only one occurrence noted in ST4. More than 50\% (40 instances) of the findings come from seven outputs produced for ST1, where they are all connected with negative assessment (Examples 15-19).

(15) [1-4O-8-M] niewiele osób aplikuje o możliwość wyjazdu few people apply for the possibility of going abroad [fewer of you . . . have applied for participation in the Life Long Learning Programmes]

(16) [1-5O-2-M] nawet jeśli część osób tego chce, to nie traktuje tego zbyt poważnie even if some people want it, they do not treat it very seriously [even if you do, you do not treat your participation seriously]

(17) $[1-5 \mathrm{O}-10-\mathrm{F}]$ studenci rozwinęli w sobie bardzo zły zwyczaj unikania wszelkich kursów

students have developed a very bad habit of avoiding all courses [you have developed a habit of missing out the courses]

(18) [1-4T-15-F] studenci wyjeżdżający na stypendia nie korzystają także z dodatkowych zajęć

students going on scholarships do not benefit from additional classes either [you refuse to enrol on any extra courses] 
(19) [1-5O-4-F] studenci zbyt głośno się zachowują students are too loud [you are too loud in the campuses]

This manipulation results in criticism being deflected from its original target, the audience, to another group (not incompatible with the addressees), the blame for the state of affairs apparently laid on a third party, not involved in the communication event.

In ST2, 31 instances of second-person to third-person plural shift were recorded in 8 outputs in focal points involving direct praise (Examples 20-22).

(20) $[2-5 \mathrm{O}-2-\mathrm{M}]$ przyszli nauczyciele świetnie sobie radzą future teachers are doing great [you excel in teaching skills]

(21) [2-4T-2-M] studenci kierunków tłumaczeniowych bardzo dobrze sobie radzą students of translation are doing very well [you have done an excellent job here]

(22) [2-4T-15-F] [wspaniali nauczyciele] mają bardzo dobrą reputację na uczelniach, na których pracują za granicą [great teachers] have a very good reputation at universities where they work abroad [you ... have already established a reputation as well-prepared, motivating and passionate teachers]

It is worth noting that in this group we counted also the few metonymic expressions that appeared (Example 23).

(23) $[2-5 \mathrm{O}-4-\mathrm{F}]$ wydział anglistyki wypadł bardzo dobrze faculty of English have performed very well [you, students of English at the University of Silesia, have managed to establish and successfully develop five student societies]

The effect of these shifts in ST2 resembles shifts noted in ST1 for critical remarks - instead of being levelled directly at the audience, the praise reaches them only indirectly, seemingly through a party not participating in this communicative event.

As regards ST4, only one such shift was recorded, realised through a rather wideranging metonymy (Example 24). This case is actually ambiguous in that it can also be interpreted as a YOU to WE shift, with WE expressed metonymically as Great Britain.

(24) [4-4T-1-M] wielka brytania osiągnęła bardzo wiele na tych igrzyskach Great Britain has achieved a lot in these Olympic games [you have shown the world that Britain has still a lot to contribute]

It is worth noting that while the number of second-person to third-person plural shifts in the control text sample may appear quite high, all the 11 instances were noted in the opening paragraph of the speech and involved the welcoming address, where the third-person form appears to be the most natural choice in Polish (Example 25).

(25) [5-4T-7-F] chciałbym tutaj szczególnie powitać przedsiębiorców, brokerów oraz ludzi [selfcor.] innych ludzi

I would like to welcome in particular entrepreneurs, brokers and other people [I want to welcome you all, entrepreneurs, agents and brokers] 


\section{Concluding Remarks}

The results of this analysis are summarised in Figure 1.

FIGURE 1

Deictic shifts: a summary for all STs - Number of first person singular and second person pronouns in the subject position in STs 1-4 stable

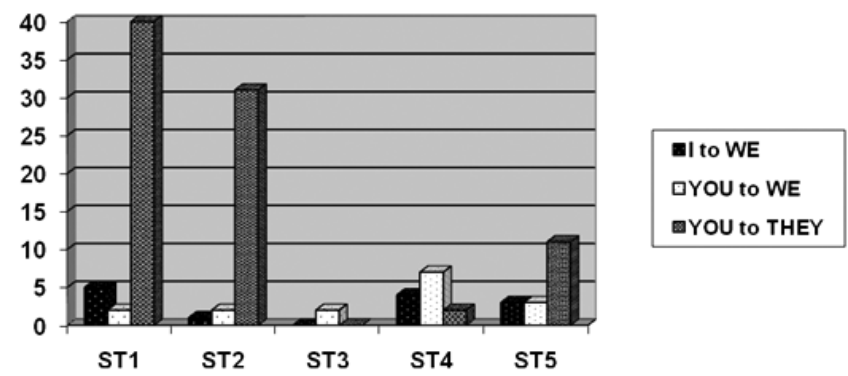

We propose to relate these results to the concept of face and face-work in which communicators engage. Direct criticism, exemplified by STs 1 and 3, is a bald act threatening the positive face of the interactant, his or her desire "to be ratified, understood, approved of, liked or admired" (Brown and Levinson 1987: 62), here undertaken without redressive action, that is, without attempt to minimise the threat to face. A threat or warning, present in ST1, threatens the negative face of the receiver by impeding his or her action by specific sanctions (Brown and Levinson 1987: 66). At least in some cultures (see, e.g., Arabski's 2003 account of responses to compliments in Polish), direct praise (STs 2 and 4), like a compliment, poses face-problems when it comes to reacting to it. In order to avoid self-praise, which constitutes a threat to the other participant's positive face by placing the speaker on a higher position, one may feel constrained to reject it by minimising the value of the object of praise, in this way damaging one's own positive face or the interlocutor's positive face - by introducing disagreement (Brown and Levinson 1987: 68; Karafoti 2007).

Another factor that we propose to take into account is solidarity, or "more or less interactionally relevant achieved 'likeness' of interacting individuals in some respect or respects" (Silverstein 2003: 205), and in-group loyalty that may result from this relationship. We assume that one way in which solidarity can be displayed in discourse is manipulation that aims at protecting face of the group with which the speaker identifies along certain lines.

As regards first-person singular to first-person plural shifts, there is a contrast between results obtained for STs 1 and 4, where such changes are more common, and STs 2 and 3, where they are rare or absent. In the outputs produced for ST1 exclusive WE refers to the institution which has the authority to supervise and evaluate and to the speaker as part of the institution. By manipulating the deictic centre, the responsibility for the negative assessment is transferred from the speaker to an absent body, which on the one hand alleviates the threat to receivers' face and on the other gives institutional force to the assessment, thereby protecting the speaker-interpreter. It is worth noting that not a single instance of this shift was recorded in ST3, also heavily critical, where there is no reason to suspect solidarity between the interpreter and the object of criticism. 
In contrast to ST1, in ST4 exclusive WE does not refer to an institution that has the authority to evaluate and control, but to all those who benefit from the success and who are grateful for the team's efforts. In this case positive politeness is enhanced by ascribing the positive opinion not only to the primary speaker but to all those on whose behalf he might be taken to speak. Interestingly, exclusive WE shifts, apparently adding to the force of a compliment, were absent from ST2, where the interpreter is at the same time the object of praise. This is in agreement with the findings of Jakubowska (1999), who argues that:

Polish responses to compliments can be put to the same categories as their English counterparts, but their frequency of occurrence differs. Self-praise-avoiding responses are prevalent, especially those which downgrade the praise of Rc (recipient), or which reject the compliment or disagree with its force. (Jakubowska 1999: 86)

With regard to second-person to first-person plural shifts, all involving inclusive WE (with one ambiguous instance), their distribution in STs 1, 2 and 3 was even. In ST1 they point to the fact that the interpreters identify with the audience, their fellow students. This use is limited to the initial portion of the text, before the critical force of the text can be appreciated by the interpreter.

In the output for ST3, the shift creates an impression of the responsibility for the plight of the Australian team being shared between the speaker and the team members, which alleviates the critical force of the text and - in the eyes of the Polish receivers of the TT - establishes solidarity between the speaker on the one hand and the object of evaluation on the other.

The greatest number of YOU to WE shifts were observed in ST4, where they background the agent whose actions brought success or allow the speaker to participate in the glory. The role of these shifts in the outputs produced for ST2 is similar, but the scale of their use is much smaller. This may point to the fact that this 'identification with success' is performed on behalf of the primary sender rather than the interpreter - it is easier for the primary sender to identify with the success of the team in ST4 than with the success of the students in ST2.

As regards second-person to third-person plural shifts, these are by far most common in STs 1 and 2, that is, in the texts where the interpreter can be expected to empathise with the audience. Most frequent in the interpretations for ST1, they alleviate criticism by not laying the blame for the state of affairs explicitly on the hearers. We find it particularly noteworthy that no such instances were observed in ST3, where the interpreter cannot be regarded as involved. With regard to ST2, the shift may be interpreted as an attempt to avoid self-praise if we take into account the student-self of the interpreter.

The picture that emerges from these observations suggests that the main factor underlying the deictic shifts discussed above is in-group loyalty and group face. Our interpreters "negotiate allegiances" (Angermeyer 2009: 4) by alleviating criticism levelled at the group with which they identify and dissociating themselves from the source of criticism by first-person singular to first-person plural shifts. Moreover, they avoid laying the blame directly on the audience with which they empathise and shun self-praise by second-person to third-person plural shifts. It is especially with respect to the last-mentioned transformation that the outputs obtained for STs 1 and 2 are more similar to each other than to any of the other two texts. Shifts that can be 
attributed to either critical or complimentary effect of the ST can be perceived only after this apparently primary distinction is made. In order to determine the extent to which in-group loyalty of the interpreter is imprinted on the output, more research is needed, the present study allowing only a modest insight into the matter in the educational context.

\section{NOTES}

1. We wish to thank our colleagues, Andrzej Porzuczek, Arkadiusz Rojczyk and Krzysztof Szymczak, who have shown truly impressive acting skills we would never have suspected them to have, and produced excellent recordings of the STs.

2. Literal translation of the Polish TT is given in italics; a corresponding fragment of the ST is enclosed in square brackets; points of special interest - here verb forms marked for person - are given in bold.

\section{REFERENCES}

Angermeyer, Philipp (2005a): Who is 'I'? Pronoun choice and bilingual identity in court interpreting. University of Pennsylvania Working Papers in Linguistics. 11(2):31-44.

Angermeyer, Philipp (2005b): Who is 'you'? Polite forms of address and ambiguous participant roles in court interpreting. Target. 17(2):203-226.

Angermeyer, Philipp (2009): Translation style and participant roles in court interpreting. Journal of Sociolinguistics. 13(1):3-28.

Arabski, Janusz (2003): Compliment responses in a cross-cultural perspective. In: Janusz Arabsкi, ed. Pragmatics and Language Learning. Kraków: Universitas, 11-19.

BeLL, Roger (1991): Translation and Translating: Theory and Practice. London: Longman.

Brown, Penelope and Levinson, Stephen (1987): Politeness: Some Universals in Language Usage. Cambridge: Cambridge University Press.

Cooper, Cary L., Davies, Rachel and Tung, Rosalie L. (1982): Interpreting stress: Sources of job stress among conference interpreters. Multilingua. 1(2):97-108.

Eelen, Gino (2001): A Critique of Politeness Theories. Manchester: St. Jerome.

EHLICH, Konrad (1992): On the historicity of politeness. In: Richard J. WATTS, Sachiko IdE and Konrad Ehlich, eds. Politeness in Language: Studies in its History, Theory and Practice. Berlin: Mouton de Gruyter, 71-107.

Fillmore, Charles J. (1971): Toward a theory of deixis. University of Hawaii Working Papers in Linguistics. 3:219-242.

Fowler, Roger (1991): Language in the News. Discourse and Ideology in the Press. London: Routledge.

Fraser, Bruce (1990): Perspectives on politeness. Journal of Pragmatics. 14(2):219-236.

GoFfman, Erving (1967): Interaction Ritual: Essays on Face-to-Face Behaviour. Harmondsworth: Penguin Books.

Hatim, Basil and Mason, Ian (1997): The Translator as Communicator. London: Routledge.

House, Juliane (2005): Politeness in Germany: Politeness in Germany? In: Leo Hickey and Miranda Stewart, eds. Politeness in Europe. Clevedon: Multilingual Matters, 13-28.

JACOBSEN, Bente (2008): Interactional pragmatics and court interpreting: An analysis of face. Interpreting. 10(1):128-158.

Jakubowska, Ewa (1999): Cross-Cultural Dimensions of Politeness in the Case of Polish and English. Katowice: Wydawnictwo Uniwersytetu Śląskiego.

Jiménez Ivars, Amparo and Pinazo Calatayud, Daniel (2001): "I failed because I got very nervous". Anxiety and performance in interpreter trainees: An empirical study. The Interpreters' Newsletter. 11:105-118.

Karafoti, Eleni (2007): Politeness, gender and the face of the speaker. In: Rachel Arscott, Katherine Barden, Arti Krishna, et al., eds. CamLing 2007. Cambridge: Cambridge Institute of Language Research, 120-126. 
KASPER, Gabriele (1990): Linguistic politeness: Current research issues. Journal of Pragmatics. 14(2):193-218.

KuRZ, Ingrid (1997): Interpreters: Stress and Situation-Dependent Control of Anxiety. In: Kinga KLAUdy and Janos KoHn, eds. Transferre necesse est. Proceedings of the $2^{\text {nd }}$ international conference on current trends in studies of translation and interpreting. Budapest: Scholastica, 201-206.

KuRz, Ingrid (2001): Conference interpreting: quality in the ears of the user. Meta. 46(2):394-409.

Leung, Ester and GibBons, John (2008): Who is responsible? Participant roles in legal interpreting cases. Multilingua. 27:177-191.

Locher, Miriam and Watts, Richard J. (2005): Politeness theory and relational work. Journal of Politeness Research. 1(1):9-33.

Łyda, Andrzej, Warcha£, Krystyna and Jackiewicz, Alina (2011): Czy czynnik płci ma znaczenie w nauczaniu przekładu ustnego? [Is gender a factor in teaching interpreting?]. In: Przemysław JaniKowski, ed. Z zagadnień dydaktyki tłumaczenia ustnego. Częstochowa: WSL.

Mason, Ian and Stewart, Miranda (2001): Interactional pragmatics, face and the dialogue interpreter. In: Ian MAson, ed. Triadic exchanges: studies in dialogue interpreting. Manchester: St. Jerome, 51-70.

MonaCelli, Claudia (2009): Self-Preservation in Simultaneous Interpreting: Surviving the Role. Amsterdam: John Benjamins.

Newmark, Peter (1988): A Textbook of Translation. New York: Prentice Hall.

PöchHACKeR, Franz (2001): Quality assessment in conference and community interpreting. Meta. 46(2):410-425.

Silverstein, Michael (2003): Indexical order and the dialectics of sociolinguistic life. Language and Communication. 23(3):193-229.

Simpson, Paul (1993): Language, Ideology and Point of View. London: Routledge.

Spencer-Oatey, Helen (2000): Rapport management. In: Helen Spencer-Oatey, ed. Culturally Speaking - Managing Rapport Through Talk Across Cultures. London: Continuum, 11-46.

Verschueren, Jef (1999): Understanding Pragmatics. London: Arnold.

Watts, Richard J. (2003): Politeness. Cambridge: Cambridge University Press.

Wong, Dongfeng and Shen, Dan (1999): Factors influencing the process of translating. Meta. 44(1):78-100.

ZitAWI, Jehan (2008): Disney comics in the Arab culture(s): a pragmatic perspective. In: Federico Zanettin, ed. Comics in Translation. Manchester: St. Jerome, 152-171.

\section{APPENDICES}

\section{Appendix 1 - Source Text 1}

Ladies and Gentlemen, Students of English at the University of Silesia,

It's a pleasure to be able to meet you here, in this new and modern site, which this Faculty and above all you, future teachers, translators, interpreters and researchers have deserved for a long time and for which you had to wait for too long. I'm proud that I represent an institution which contributed to the successful completion of this project, whose ultimate purpose was, and let me spell this out very clearly, to provide you, students, with better conditions for self-development and to create an atmosphere conducive to asking questions, pursuing answers and establishing international student networks - networks that will in future develop into firm, dynamic and fertile centres for improving the quality of human resource development in the context of higher education and vocational training. I'm afraid the joint effort of the University of Silesia, Sosnowiec Town Hall and European Union has not brought the fruits we all have been hoping for.

As Co-ordinator for Student Mobility, it is with sad disappointment that I noticed that you do not show more interest in international exchange projects than three or four years ago, when there were fewer opportunities to study abroad and less encouragement to do so. 
Actually fewer of you, students of English at this Faculty, I might think well-prepared for such co-operation in terms of language competence and translation skills, have applied for participation in the Life Long Learning Programmes in this academic year than in the two previous years together! Not only are you reluctant to embark on such now widely available projects, but even if you do, you do not treat your participation seriously. From the reports I regularly receive from the Host Institutions, I know that you have developed a habit of missing out the courses offered, with the result that you come back with a lower ECTS score than you should, which is of course unacceptable. Let me be clear on this point, if you persist in this deplorable practice, as Co-ordinator for Student Mobility I will have to impose financial penalties on your Home Institution.

Another worrying symptom of your low motivation for self-development is that you refuse to enrol on any extra courses that Host Institutions offer to Erasmus students, and which reflect their special profiles and interests. Rather than benefit from the Host's competence and experience in a particular area of study, you take the line of least resistance sticking to the minimum ECTS requirements, if you meet them at all, which, as I said, is not the case.

The last issue I have to raise, however unwillingly, is the problem of conduct and social norms which apply in the host countries and which you notoriously ignore. Apart from missing obligatory courses, you persist in breaking the no-smoking regulations, which are now very strict and very clear at the same time. Moreover, while I don't want to pretend I have the authority to ask you to curb your drinking habits, I must insist on your controlling your behaviour once you have already had too much. In short, you are too loud in the campuses and you effectively prevent other students from pursuing their studies. I regret to tell you that in this way you are doing your Home Institution a disservice. Even more do I regret to have to tell you this in these modern, inspiring and motivating settings. I will be looking forward to meeting you here next year, hoping to have warmer things to say.

Thank you very much for your attention.

\section{Appendix 2 - Source Text 2}

Ladies and Gentlemen, Students of English at the University of Silesia,

I hardly need to tell you how happy I am to be here, in this wonderful, modern site, and how impressed I am to see that in such a short period of time you have managed to turn it into a homely place, radiating positive energy and wrapped in stimulating atmosphere. And impressed as I am with these spacious, high-tech rooms and halls, I know it's not walls that have made this building into a dynamic centre of research and education. This energy and this atmosphere have not come from glass or steel, they have come from you.

As Co-ordinator for Human Resource Development, now visiting and evaluating higher education institutions co-operating in the framework of European Union, I note with enormous satisfaction that you, students of English at the University of Silesia, have managed to establish and successfully develop five student societies - a truly academic achievement very few student communities can boast. Still fewer can pride themselves on founding a society that has won recognition on a regional scale, as you can with your Arabic Culture Society. In three other cases - the Student Societies for Translation Studies, for Historical and General Linguistics and for Theatrology - you have succeeded in drawing your colleagues from other institutes, which is a remarkable and telling success in times when the number of young people willing to spend their leisure on academic pursuits and discussions is steadily decreasing. With your enthusiasm and vivid, inquisitive minds you have shown the rest of your community that shared scholarly passions can become a rich source of satisfaction and - yes, I will use this word - fun.

It would be a huge mistake if I failed to mention that you perform exceptionally well on proficiency tests which European universities hold for visiting students. The reports that 
reach me from various host institutions speak in a single voice - for three years now you have shown very high levels of language competence and invariably scored very high in tests for Speakers of English as a Second/Foreign Language. Moreover, in teacher training courses held now by a number of European universities, you excel in teaching skills and have already established a reputation as well-prepared, motivating and passionate teachers.

Impressed with your language skills and teaching potential, now I'd like to address those of you who pursue the demanding translation studies - you have done an excellent job here with your conference interpreting and translation courses involving German and Arabic. What I'd like to note is that not only did you pioneer a programme with language $\mathrm{C}$ representing typologically a distant system, but you are eager to incorporate your language C competence when doing research for your MA degrees as well. Secondly, and this is a point I find exceptionally important, as a group of students undergoing a very comprehensive translation training, you play a crucial role in the international exchange programmes operating between the University of Silesia and Universities in Vienna, Amsterdam and Bologne. It is with these institutions that you have managed to establish a regular exchange. This mobility became the basis for a translation student network that you have started and later developed into an invaluable source of information, offering mutual access to data bases and translation corpora.

Last but not least, I feel this account of your achievements would be incomplete if I ignored the important aspect of presenting research and sharing ideas with others. You actively participate in international meetings and conferences for young linguists and trainee interpreters, both at home and abroad, for instance last year in Split, Poznań and Łódź, where I had the pleasure of talking to some of you. As part of your Student Societies activities, you organize informal lectures and presentations for your colleagues from other institutes of this Faculty. You participate actively in the life of student community writing to international student magazines, like Alumnus and Focus on College. With all this I won't exaggerate if I say that today you set an example for your fellow students at other European universities.

Thank you very much for your excellent work.

\section{Appendix 3 - Source Text 3}

Ladies and Gentlemen, Sportsmen and Sportswomen, members of the Australian Olympic Team,

I'm pleased to meet you here, on the hospitable premises of this newly-erected, modern Olympics Sports Centre, whose aim from the start was to cater for your needs and to provide you, promising athletes of this land, the optimum conditions for training and development. I'm proud that I represent an institution which contributed to the successful completion of the project, which is now one of the finest examples of modern sports architecture, fitted with facilities very few such centres in the world can boast. And proud as I am that I've had my modest share in fostering Australia's sporting culture, I'm afraid the joint effort of four official sponsors of the Australian Olympic Team has not brought the fruits we all have been hoping for.

As President of the Australian Wines and sports fan deeply concerned about Australian long-established sporting tradition, I note with dismay that you thwarted the enthusiasm of the Australian people, let down young sports lovers and seriously disappointed your fellow athletes who could not represent their country in the Olympic Games this year but supported you throughout these two weeks with their hopes, good wishes and strength coming from real devotion to Olympic ideals. Of the planned 65 medals - a number that in your conceit you prematurely boosted to 70 in the interview just before the flight to Beijing - you managed to gather only 46. And while I appreciate and thank you for the 14 golds, 15 silvers and 17 bronze medals you came back with, I cannot help wringing my 
hands at the thought of the Australian Olympic Team relegated to the position behind Germany and Great Britain. I cannot believe that within just two weeks you demoted this country, whose enthusiasm for and devotion to sports competition and Olympic ideals had become legendary, to the status of mediocrity. The real problem, however, lies not in the number of honours you received or, I should say, you failed to receive, but in the nonchalant disposition you showed while preparing for the Games and during the two weeks in Beijing, as well as in the disturbingly self-complacent attitude you have manifested since your rather infamous return. Attitude which I consider thoroughly unacceptable.

As a sponsor of the Australian 2008 Olympic Team I find it truly regrettable that instead of benefiting from the excellent conditions that the Olympics Sports Centre now offers, you practiced only half-heartedly in your home clubs, claiming that you had already shown the public during the previous Olympic Games what an unbeatable, invincible and versatile team you were! You refused to take advantage of advice offered by professional analysts, who had warned repeatedly that Britain's swimming power was growing. You laughed off the preposterous idea that young Asian teams were a real threat to Australian athletes. When the Games were already in full swing you openly ridiculed the suggestion that Germans could score higher in the final ranking than you! What a deplorable lack of self-criticism and elementary prudence you showed! I regret to tell you that through your arrogance you have brought dishonour to the Australian Olympic Association and belied the best Australian sporting traditions. With all this I cannot but tell you today that you have succeeded in turning this year's Olympics into the blackest days of Australian sport.

Thank you for your attention.

\section{Appendix 4 - Source Text 4}

Ladies and Gentlemen, Sportsmen and Sportswomen, members of the British Olympic Team,

when I stood here before you a month ago, I hoped with all my heart that the last four years of hard work, uncompromising self-discipline and - yes, in many cases austere selfdenial in the name of Olympic ideals and athletic achievements might bring the fruits you all rightly deserved. I'm standing in the same place today, proud to address you, British athletes, medallists, people of sport, upon your return from Beijing, and honoured to represent an institution which can boast the fourth Olympic Team in the world. And while I realise that the success of the Team is a joint effort of many people who contributed their time, energy and resources to this national project, nobody understands better than I do that it's you, British sportsmen and sportswomen, that endowed it with the soul, the spirit and the morale which can only come from strain, perseverance and faith. I am here today to thank you for what you have done - for yourselves, for the Olympic tradition, for Britain and for the spectators.

As President of the British Olympic Association I note with pride and enormous satisfaction that you won 47 medals, including 19 golds, which is the best Olympic performance the British Olympic Association have recorded since 1908! You achieved a spectacular success for which the British had waited for a century: you have promoted Britain to rank four, behind such Olympic giants as China, United States and Russian Federation and before such long-established sports powers like Germany and Australia. With 19 golds, 13 silvers and 15 bronze medals you have shown the world that Britain has still a lot to contribute to the world's Olympic dreams. You have proved that the tradition of sports competition, fair play and cooperation is in Britain as much alive as ever.

I don't have to tell you how truly impressed I am by the excellent, superb results that you achieved in such a vast array of disciplines and events. Of the over 40 world records broken during this year's Olympic games, you, British athletes, set more than one fifth, you were unbeatable in cycling and swimming, you excelled in sailing and rowing, you achieved 
phenomenal results in athletics, boxing and modern pentathlon. With your stamina and perseverance you gave a breath-taking performance, succeeded in drawing the British to follow the broadcasts with unwavering excitement, and kept them right there in front of their TV sets throughout the magic two weeks.

What I find exceptionally important, though, is the way in which you achieved this remarkable success. Through your attitude you have shown the world a true fidelity to Olympic ideals and to the long-standing tradition of fair-play and cooperation in competition. You have demonstrated that partnership, friendship and care for the others are not part of the Olympic myth but imperishable values that give sense and meaning to sports pursuits. I won't exaggerate if I say that it is your attitude that is the most valuable and lasting contribution to the Games - it is thorough your attitude that you shape the next generations of athletes and bring credit to this country and the best British Olympic traditions. I'm happy to be standing here in front of you today, I'm fully aware of this historic moment when I'm looking at your tired but elated faces, and I take it as an honour to be able to thank you all. Thank you.

\section{Appendix 5 - Source Text 5}

Ladies and Gentlemen, Participants of the IVth Annual State Congress of Real Estate Enterprise,

it is my privilege to address such a distinguished company of men and women. I feel honored to make the opening speech and initiate the proceedings of the IVth Annual State Congress of Real Estate Enterprise in Houston. I want to welcome you all, entrepreneurs, agents and brokers. I would love to greet you, the officials from the generous Houston Town Hall, who have agreed to host the event on their premises. Last but not least, I meet members of the State Board, thanks to whose efforts we are here now.

I presume to inform you that Houston holds the Annual State Congress of Real Estate Enterprise for the first time. The first three events took place in Austin but as a consequence of the Board's decision last year the venue is to alter on a regular basis to raise the rank of other urban areas of the state.

For me the choice of this location is remarkably touching. I guess you have known by now that I come from Houston, though I had left it almost half a century ago, choosing Stanford as my Alma Mater. I cannot resist the temptation to tell you in confidence the last time I was in this Grand Lobby of the Town Hall was on my graduation day. Shakespeare High, whose old pupil I am proud to be, found sponsors to re-decorate its foyer that spring and the ceremony took place on these hospitable premises. Well, sentiments aside.

Let me proceed to the presentation of the annual report of the Texas Association of Realtors. You will find it interesting to hear that Houston has been gaining continuous praises so far in terms of its property market activity. You all know that two years ago it ranked first in the US Census Bureau's Total Housing Market Data with a 14.7 increase. Now, it is second ... but if I tell you that it is Dallas that it yielded to, you will understand why I do not weep for it.

I feel obliged to notify you that just last month The Forbes Magazine cited Houston as the best metropolitan area to purchase homes, topping San Francisco, Charlotte and Jacksonville.

I am aware of the fact that it is not only NASA that this city prides in. You, Texan realtors, know only too well that Tech companies, such as the Houston Technological Center, $\mathrm{N}$ Tech, Geo-Tech Tool, Corr-Tech and Stone Bond Tech among others, have attracted thousands of IT and software workers to move to H-Town.

I would like to let you know, participants of the Congress, that the Bureau of Economic Analysis has found out a 9.4 increase in its residents' personal income, whose reason is the job growth in the past years. 
Another thing that I intend to bring up today is a number of significant constructions in Harris County that include the $\$ 40$ million Rotary House International Hotel and two builds already in the bid phase, namely the Texas National Guard Fire Station and the Residence Inn by Marriott. You will find it illuminating that businesses which gravitate to the area enjoy lower business taxes in a city that has welcomed investments in health care, aeronautics, manufacturing and technology. Add in the multicultural communities, reputed medical centers and universities, glitzy art scenes, and popular tourist destinations, you will agree that it has a lot to offer to potential homebuyers.

At this point, I presume to acquaint you, participants of the IVth Annual State Congress of Real Estate, with the report recently released by The Houston Association of Realtors. It says that despite sliding sales for the last few months, April 2008's 6,012 closed deals on single-family houses were actually the highest record since June of last year. You won't be surprised that Houston also boasts of record sales in townhouses and condominiums, an indication of stronger showings even if the housing slump has not waned down.

It is with optimism that I declare this Congress open and wish you all fruitful debates. 